\title{
The Sui Utik, Creative Works and Tembawang: Retaining Biodiversity in Kalimantan, Indonesia
}

\author{
Octaviana Sylvia Caroline Rombe \\ https://orcid.org/0000-0002-0244-9413
}

Bina Nusantara University, Indonesia

\begin{abstract}
This paper discusses how the Dayak Iban community of Sui Utik, Kalimantan, with the help of Sekar Kawung, a social enterprise foundation, uses the indigenous system of Tembawang to challenge deforestation and concomitant problems of air pollution through creative works based on the materials of the local rainforest. The research for this paper includes interviews with the founder of Sekar Kawung foundation, literature reviews, photographs, social media reports and community summaries. Sui Utik, in collaboration with Sekar Kawung, has developed creative works including weavings, an innovative application of tattoos, food and beverage products, and eco treks. The research found that the Sui Utik community, which started producing creative works in 2015 , have continued their practice as social entrepreneurs. It is suggested that they should now expand their practice by working together with other indigenous entrepreneurs to challenge Indonesian craftsmen and designers to take their creativity, skills and knowledge to an international market. As part of this move, the development of innovative marketing tools using new technologies should be explored, while maintaining local wisdom as the core value for making creative works.
\end{abstract}

Keywords: Sui Utik, Tembawang, Sekar Kawung, Kalimantan, biodiversity, Indonesia, local wisdom, Dayak Iban, creative works, culture

eTropic: electronic journal of studies in the tropics publishes new research from arts, humanities, social sciences and allied fields on the variety and interrelatedness of nature, culture, and society in the tropics. Published by James Cook University, a leading research institution on critical issues facing the worlds' Tropics. Free open access, Scopus, Google Scholar, DOAJ, Crossref, Ulrich's, SHERPA/RoMEO, Pandora, ISSN 1448-2940. Creative Commons CC BY 4.0. Articles are free to download, save and reproduce. Citation: to cite this article include Author(s), title, eTropic, volume, issue, year, pages and DOI: http://dx.doi.org/10.25120/etropic.19.1.2020.3696 


\title{
Introduction
}

\begin{abstract}
A $s$ an architect and lecturer in an Indonesian school of design, my research $\Delta$ interests have extended to ways of developing value chains based on the 1 wisdom of local indigenous communities. In 2019, I met Chandra Kirana, the founder of Sekar Kawung, a social enterprise foundation, and was inspired by the foundation's work in collaboration with the Dayak Iban community of Sui Utik, West Kalimantan, Indonesian Borneo. Having undertaken research over several years into local wisdom and various community development projects in Indonesia, I believe that the example of the collaborative work between Sui Utik and Sekar Kawung is a worthy example of what can be done to embrace the concept of local wisdom incorporated with biodiversity conservation as a base for value chains of creative works in Indonesia. It is hoped that the practices in Sui Utik will inspire others.
\end{abstract}

The creative works in this paper refer to weaving, innovative application of a tattoo, indigenous food and beverage processing, and the design of eco treks - all of which have been developed with respect to the indigenous agroforestry concept of Tembawang. The system of Tembawang helps to maintain the local environment and its rich biodiversity in the face of encroaching deforestation in Kalimantan and further across the island of Borneo. This is in keeping with Sekar Kawung's social enterprise objective which is to assist indigenous communities to continue to protect the biodiversity of their lands, while enabling their cultures to thrive by helping them to create sustainable social and economic projects in their villages (Kirana, 2019).

Research for this paper includes interviews with the founder of Sekar Kawung, and incorporates qualitative data from literature reviews, photographs, social media reports, and community summaries. The paper firstly sets out the broader background issue of deforestation and pollution in the Indonesia context; it then outlines the indigenous concept of Tembawang; introduces Sekar Kawang and the community of Sui Utik; and proceeds to discuss the creative works in the context of value chains of production, and how the concept of Tembawang is embedded in the products. The paper finishes by proposing that the creative products be expanded to an international market and the development of marketing tools using new technologies.

Importantly, the value chains of the creative works produced in Sui Utik support Indonesian local tradition and biodiversity through the indigenous concept of Tembawang. The restoration of biodiversity through the Tembawang system challenges the issue of pollution as a result of deforestation and unmanaged land clearance in Kalimantan, Borneo. 


\section{Deforestation}

Indigenous people have sustained and been sustained by rainforests for centuries (Rainforest Action Network, 2019). A WWF study undertaken in 2012 projected that deforestation rates in Malaysian and Indonesian Borneo would see the loss of 21.5 million hectares of forest between 2007 and 2020. This outcome would reduce the remaining forest to only 24 per cent. In this scenario, this island - the world's third largest - would lose most of its lowland rainforests outside of protected areas by 2020 (WWF, 2019). We have now reached this era and the serious plight of deforestation continues to be of major concern.

Deforestation "involves change in forest uses to other purposes through activities that destroy forests so that forests permanently [lose] vegetation" (Susanto et al., 2018, p. 513). Forest fires caused by unmanaged land clearance methods which utilize the dry season as a simple and inexpensive way to burn large areas of land contribute to deforestation (Idhom, 2019, para 18). No matter where it occurs, large scale deforestation has 'an effect on global air quality' which affects the air we breathe. "This inevitably results in all of us breathing dirtier and more polluted air" (PACWA, 2019). The situation in Indonesia has often caused regional cross border alarm regarding high levels of air pollution. A report on the situation in 2019 included data from Indonesia's Disaster Mitigation Agency which stated that "more than 3,600 fires had been detected on the islands of Sumatra and Borneo by weather satellites, leading to very poor air quality in six provinces with a combined population of more than 23 million" (Lamb, 2019, para 6).

The resulting air pollution from forest fires every year have caused acute respiratory infections in people, severe disruptions in air traffic, the temporary closures of schools in parts of Sumatra and Kalimantan and affected the health of children. During the last forest fire in September 2019 in Riau, Sumatra, it was noted that children were getting weaker, did not want to eat, had high body temperatures and doctors found bacteria in their bodies due to the smog (Antaranews, 2019). In Central Kalimantan, not only human beings, but animals became victims of the fires since the forests are home to indigenous fauna. Many of those animals left their habitat to avoid the fires and were found to be suffering from respiratory illnesses (Antaranews, 2019).

Deforestation not only causes air pollution, it also impacts the economy of people reliant on ecosystems and biodiversity. According to The Economics of Ecosystems and Biodiversity (TEEB) initiative, 99 million Indonesians are dependent on ecosystem services for their livelihoods. Ecosystem services, as defined by the Millennium Ecosystem Assessment (MEA), are "the benefits that people obtain from ecosystems" (Millennium Ecosystems Assessment, 2005, p. V). As observed by Baral et al. (2017), 
more recent studies have moved to refine this definition in order to improve the applicability of ecosystem services for decision-making purposes. They note The Economics of Ecosystems and Biodiversity (TEEB) defines ecosystem services as "the direct and indirect contributions of ecosystems to human well-being" (Baral et al., 2017 , p. 2). Not only do ecosystems contribute to human well-being, but ecosystem services can provide benefits for climate change mitigation (retaining rainforests for carbon sequestration) and adaptation (enabling communities to adapt to climate variability through diversification of livelihoods). Thus, ecosystem services can enhance local livelihoods by diversifying economic activities based on traditional products and knowledge while conserving and protecting local biodiversity (Locatelli, 2016).

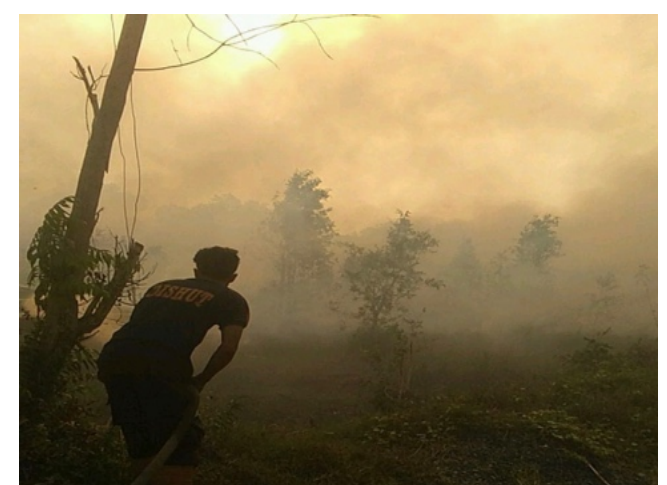

A

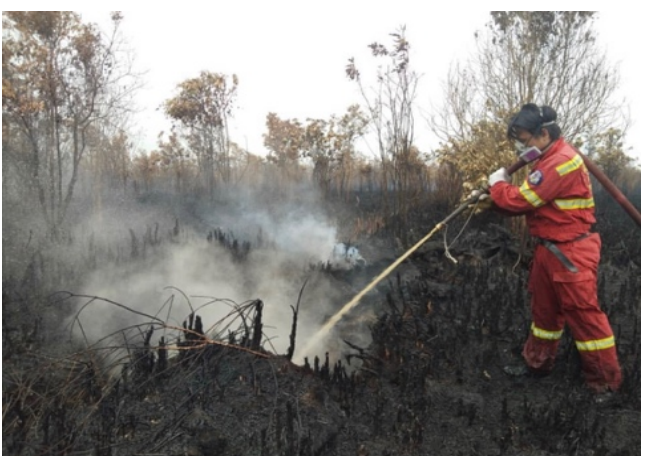

C

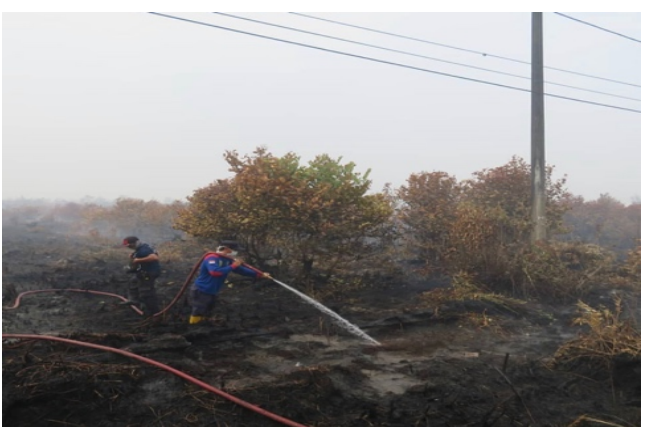

E

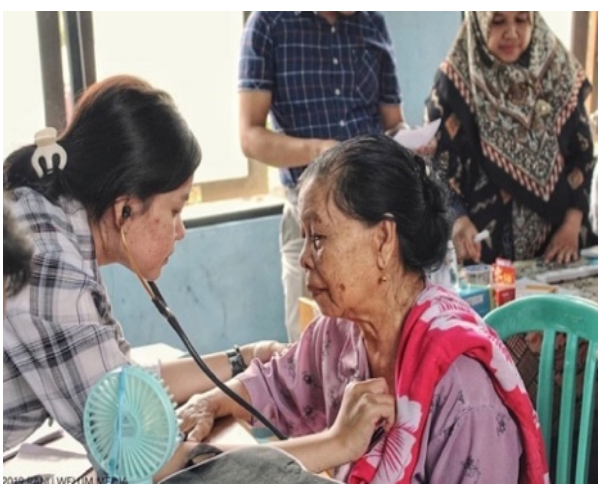

B

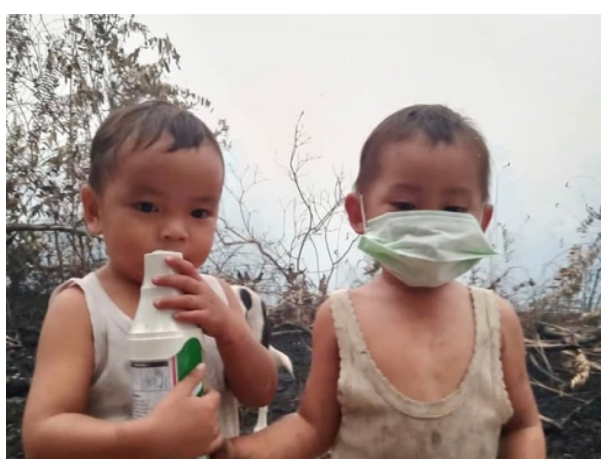

D

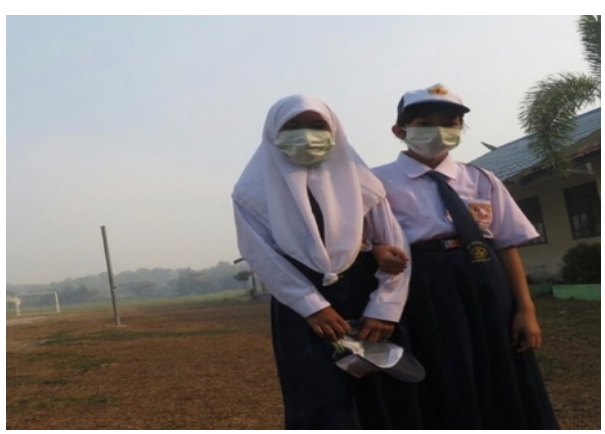

F 
Figure 1 A: Forest fires in Central Kalimantan on 2019 (Damkar, Forest Fires, 2019),

$B$. Old people were among the weakest that had been affected by the smoke of the forest fire (Youth_actkalimantan \& Ranu Welum Foundation, Old People, 2019),

C. Firefighters putting out fires in Central Kalimantan (Youth_Actkalimantan \& Ranu Welum Foundation, Firefighter in Central Kalimantan, 2019),

$D$. Babies were using masks. They were also among the weakest that had been affected by the smoke (Youth_actkalimantan \& Ranu Welum Foundation, Babies, 2019),

E. Firefighters during the forest fires in Central Kalimantan (Laman, Firefighters, 2019),

$F$. Youth wearing masks to counter the smoke haze in Kalimantan (Ananda, Children, 2019)

\section{The Tembawang system}

Mismanagement of forests and ecosystems, which has resulted in deforestation, stands in contrast to the indigenous Dayak system called Tembawang. This community level resource management system relies on local wisdom which consults a seasonal calendar in determining planting and land clearing schedules (Muryati \& Rokhiman, 2016). Within this system, fire is used as a tool of land clearing; however, in contradistinction to the practice used by large companies where forest burning is utilized as a cheap method for land clearing on a massive scale, Dayak local wisdom calls for 'bambi ari' in which communities clear small land areas in accordance with seasons and collaborate to ensure the monitoring of fire hot spots and local supplies of water to prevent uncontrolled forest fires.

These small areas of seasonal clearing are combined with practices of reforestation to produce an ecology of agroforests within rainforests. In brief, Tembawang is a traditional forest grown in areas used in indigenous farming, hunting, gathering and sites of community long houses. It is classified as a complex agroforestry and comprises large tree, shrubs, seasonal plants and grasses - including medicinal plants, handicraft materials, fruit trees etc. Tembawang forests may occur as overgrowth of former community houses or in extant settlements bordering and mingling with rainforests. According to Bambang Soeharto, a researcher in natural resource and environment management from Bogor Agricultural University, Indonesia, Tembawang (also called Agroforest Tembawang) is a land use system of the Dayak peoples of West Kalimantan, incorporating various types of plants, ranging from large trees with a diameter greater than one metre, to small herbaceous plants. The system incorporates agricultural techniques in accordance with local wisdom and social rules. These techniques, involving plant use and rehabilitation, serve to form an intermingling of agriculture and forest resembling a natural forest ecosystem. The value of this system is not only in its complex biodiversity, but it is a source of economic value, as well as embracing moral values of conservation (Soeharto, 2010, p. 10).

Three main elements of conservation are protection, preservation and utilization. Protection and preservation incorporate cultural social values, including sustaining the 
needs of generations to come, while utilization reflects economic value. In this sense, the meaning of conservation is not merely protection or preservation, but also encompasses utilization. The social values of the culture and the integrated economy create an ecological value (Soeharto, 2010, p. 10).

The complexity of the Tembawang system means it is more than just agroforestry. In addition to maintaining ecological systems and biodiversity, the system also retains cultural heritage, indigenous knowledge, and spiritual practices - all of which are passed from one generation to the next. These are characteristic values of Indigenous rainforest dwellers of the tropics (Aaberge et al. 2014, p.10). As noted in the research by Soeharto: Tembawang is beneficial as a genetic resource for conservation both insitu and ex-situ and as an ecological sac for wild species; it is an important source of livelihood for Dayak Iban tribes; it has socio-cultural values that are preserved for generations to come; and is a tradition conserved in generations, including ancestral (Soeharto, 2010, p. 11). As the science researcher observes, Tembawang "contains values that are very sublime" (Soeharto, 2010, p. 10).

Given the effects deforestation and unmanaged land clearance have on local indigenous peoples' lives, as well as the negative impact on the forest's economic growth, it is timely to review the practices of social entrepreneurs who incorporate ecological principles in their production practices. The social entrepreneurs in Sui Utik, [English: Utik river] West Kalimantan, in consultation with Sekar Kawung foundation, have created a sustainable value chain by using the local wisdom of Tembawang where the creative works use material sources from the agroforest and rainforest surrounding the Utik river.

\section{Sekar Kawung meets Sui Utik}

Sekar Kawung was founded by Chandra Kirana to help indigenous peoples to continue to protect the biodiversity of their land while enabling their cultures to thrive, and at the same time helping them create and maintain sustainable socio-economic projects in their communities. In 2013, when the idea of Sekar Kawung was first conceived, Kirana was working as the Green Economic Initiatives Director for Daemeter, a sustainability consulting firm. She had invited the Indonesian Nature Film Society (INFIS) to collaborate in preparing and executing an exhibition. By mid 2014, Kirana moved to INFIS, leaving the consultancy world to focus fully on promoting green economic development with local communities through the INFIS' Green Indonesia social enterprise. However, in late 2016, the INFIS Board of Directors decided that the organization should focus solely on film making, and Green Indonesia was encouraged to spin off into its own entity, with Kirana as director. This robust 
background in environmental and local community work is the backbone to Sekar Kawung Foundation, which was initiated with support from several friends as members. The team focused on helping indigenous people to build their economy, while promoting conservation of nature and the richness of their culture. In Kalimantan, with a small grant from Samdhana Institute, an Asian centre for social and environmental renewal, they accompanied the Sui Utik community to undertake participatory research of the potential cultural and intangible heritage products the community own which could be revitalized as creative products. Together with the Sui Utik community, the Sekar Kawung team dug into the unique qualities of the Utik river, its culture and its biodiversity (Kirana, 2019).

Sekar Kawung develops its concept and approach in reference to the body of research about traditional agroforestry systems in Indonesia in accordance with the research produced by Geneviève Michon and Hubert De Foresta. The researchers state that: "The forest should firstly and primarily provide sources of permanent and irregular cash income for local people in order to be sustainable" (Foresta \& Michon, 1997, p. 108). They further advise that: "The economic value of the forest for smallholders and for local communities may be considered as the best warrant for its protection" (Foresta \& Michon, 1997, p. 109).

Utik river with its sophisticated agroforestry system of Tembawang, holds a viable source of ecologically sustainable materials for architecture, weaving, food and other creative forms of production (Kirana, 2019). Any creative enterprise undertaking needs to be considered with respect to the indigenous community, their traditional practice of forest management, and their ability to pass knowledge and practices on to the next generation. This is in keeping with the research and broader discussion undertaken by Foresta and Michon which influences the ethos of Sekar Kawung:

The governing authority system over the forest as a whole should be designed to facilitate adjustments in the forest management with time, adjustments which would be absolutely necessary for the forest to keep its profitability as high as possible, and therefore to keep its sustainability.... Clear rights in the transfer of forest units to the farmer's descendants should also be recognized, as this is another important incentive for managing a multi-species forest structure with a long-term perspective. (Foresta \& Michon, 1997, p. 108) 


\section{Sui Utik Creative Works}

Sui Utik is a rainforest community that lives in a traditional long house nestled within their 9600 ha of protected rainforests. Protecting the Sui Utik way of life simultaneously protects the biodiversity of plants through their Tembawang agroforestry system. As Chandra Kirana, reflects: how Sekar Kawung works with the Utik river people to help them adapt their agroforestry bounty into products for the contemporary market place, as well as developing community-based ecotourism so the Utik people can live well economically and simultaneously keep the forest intact, remains an ongoing quest (Kirana, 2019).
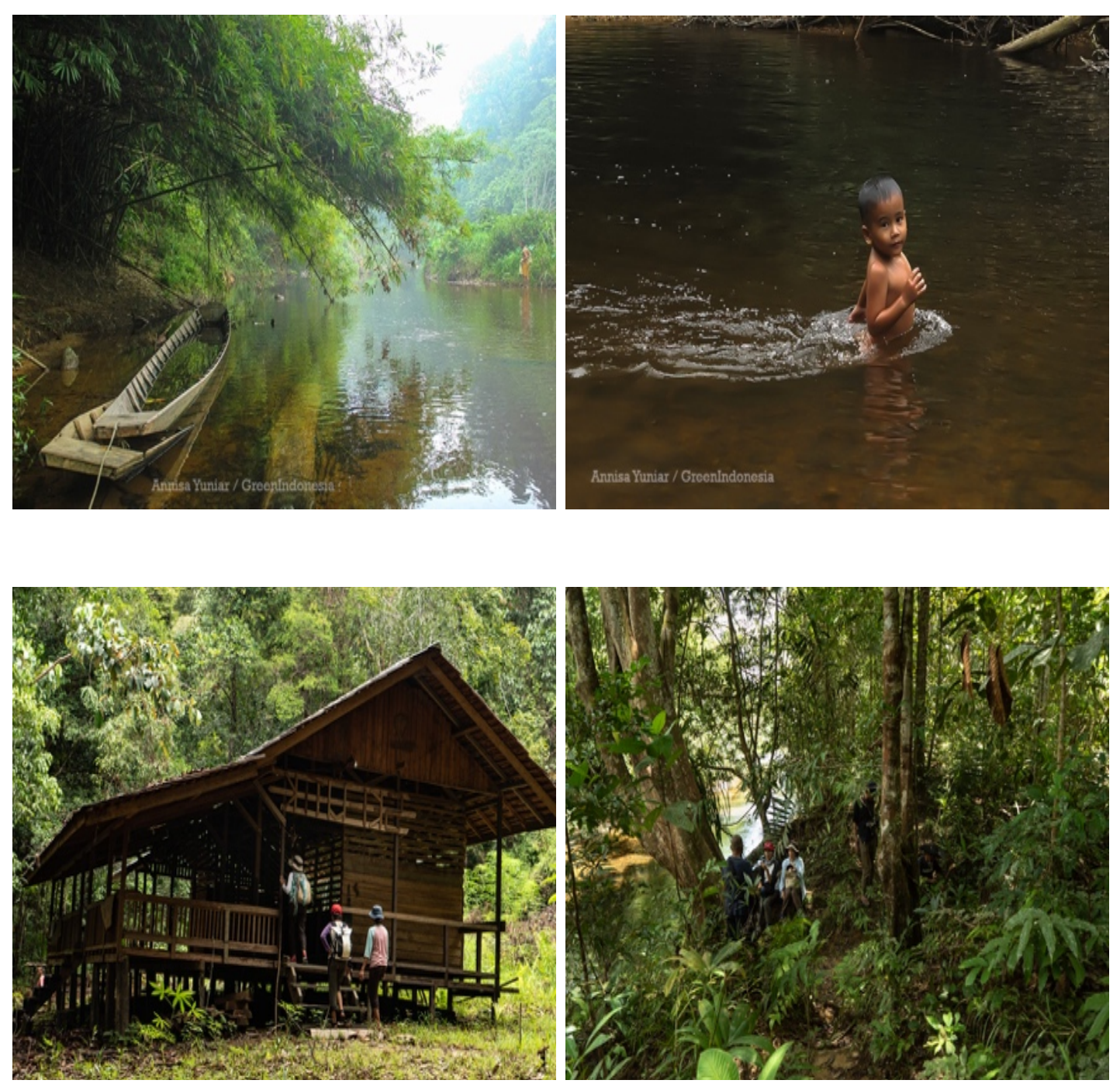

Figure 2: The natural beauty of Utik river and rainforest (Yuniar \& Kirana, Utik River and Rainforest, 2015) 

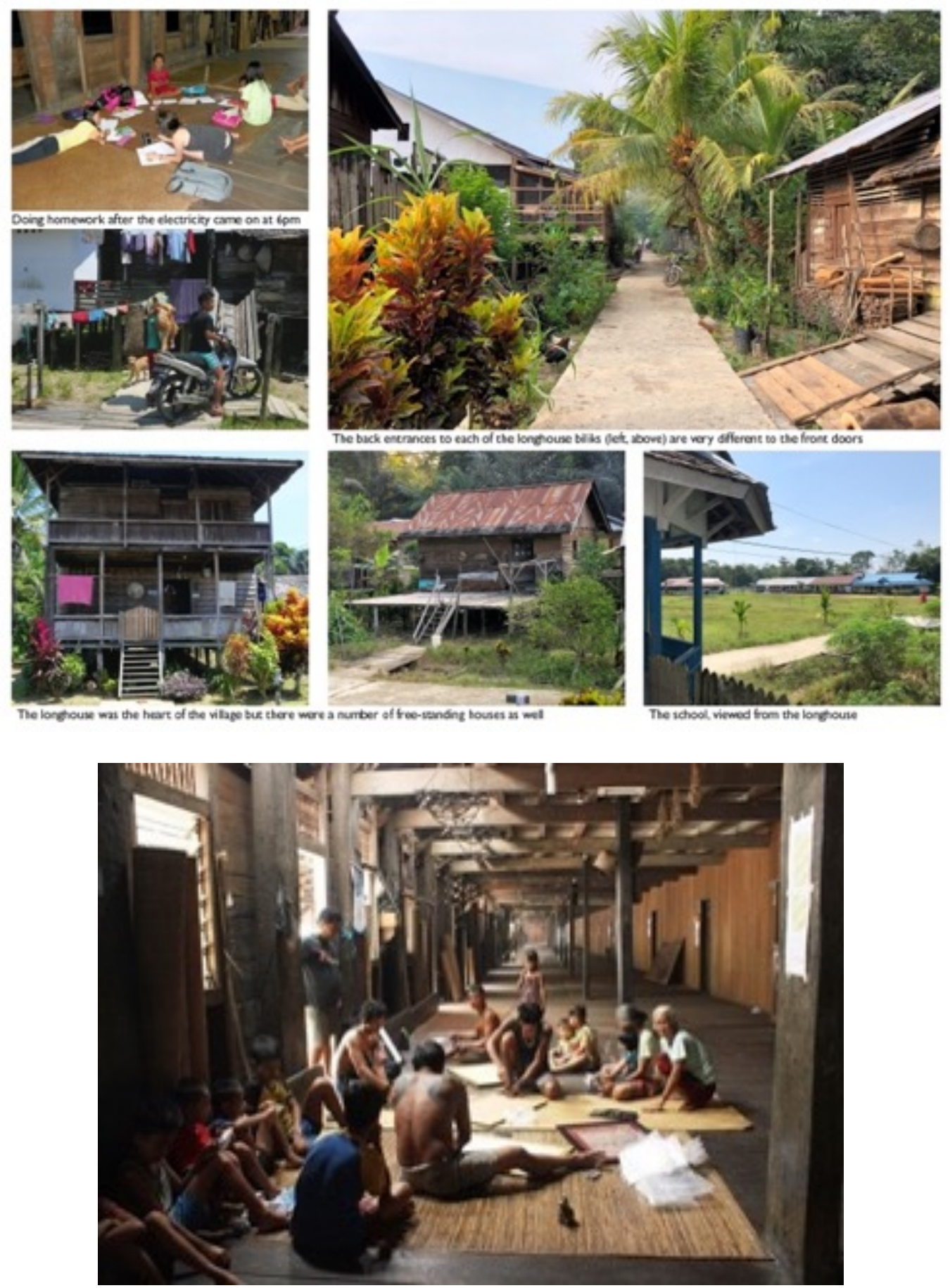

Figure 3: Sui Utik longhouse (Toisuta \& Kirana, Iban House, An Amazing Week in Sungai Utik, Iban Dayak Community, West Kalimantan, 2018)

The photographs above demonstrate daily life in Sui Utik. Figure 2 captures the natural beauty of the Utik river and rainforest with its clear waters and extensive flora that are maintained using the indigenous concept of Tembawang. Figure 3 shows several photographs portraying the community-based social structure of the Sui Utik people who live in a traditional Dayak Iban long house. 
All Sekar Kawung social enterprise efforts are carried out with the aim of creating sustainable value chains where the production and consumption of items are in harmony with nature, and where that production and consumption improves the ecological environment as well as the economic and cultural wellbeing of the people. The foundation endeavours to work from multiple angles across the various phases of the production and consumption chain. As Chandra Kirana further explains, social enterprise is not just theoretical, it comes from experience: "The lesson learned from my numerous journeys is the importance of creating a thoroughly sustainable value chain from the sourcing of materials to the marketing and the management of the product afterlife" (Kirana, 2019).

The following principles are adopted by Sekar Kawung in the proposed value chain. The first step is sourcing raw materials which have the following qualities: no artificial chemical inputs, conservative use of water, no ecological degradation, fair price for supplier, sustainable packaging, and are close to the source. No ecological degradation means preserving the environment - land, forests, air, water, soil etc from natural resource exhaustion (El-Haggar, 2007). The second step is the production process which includes: use of natural dyes, better cotton, fair price or pay for artisans, keeping artisans in business, and nurturing local or indigenous art, craft skills or heritage. The third step is branding which is: transparent and accountable, sustainable and fair, enriches local culture, and uses packaging that is able to be recycled. The fourth step is marketing which incorporates: telling the story of the making, featuring the people behind the product, and making responsible consumption easy. The fifth step is usage, which refers to: care for product in a way that is not energy intensive, water usage intensive or chemical intensive. The final link in the value chain is post-usage, which includes: long product life, recyclable, and biodegradable (see Figure 4) (Kirana, 2019).
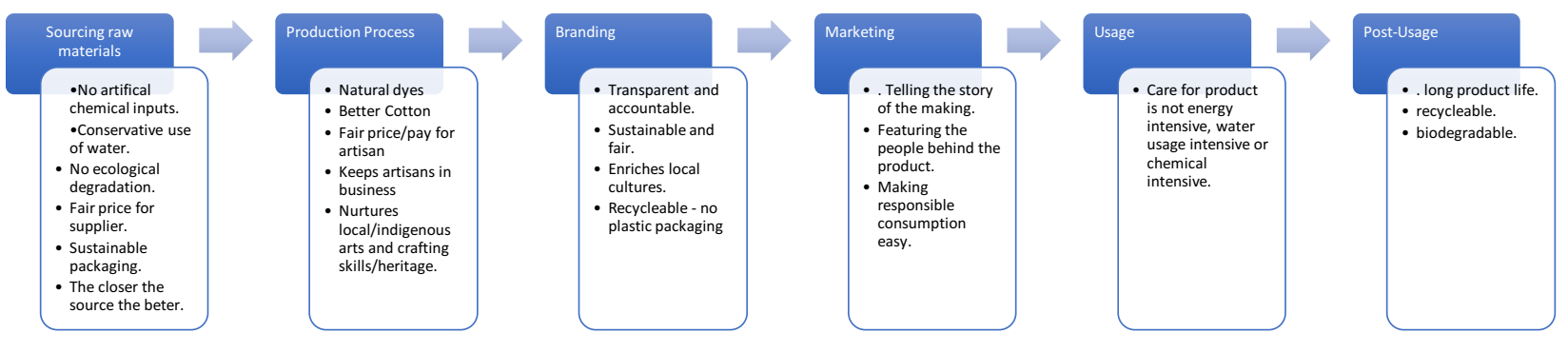

Figure 4: Value chain proposed by Sekar Kawung Foundation (Kirana, 2019)

With this insight, Sekar Kawung dedicates itself to supporting the greening of key local creative value chains. The social entrepreneurship model of Sekar Kawung, where the aim is to empower local communities and maintain sustainable outcomes - including 
ecologically, culturally and economically - demonstrated a clear vision, which has since been implemented.

In collaboration with the community of Sui Utik, Sekar Kawung helped in the development of creative works based on local indigenous concepts that express the value of sustainable development with a respectful relationship to the environment. The creative works are prepared and made under a design principle that integrates the Tembawang system and the concept of living together in a traditional long house (Kirana, 2019). These works include jewelry, mat and basket weaving, an innovative application of tattoo design, indigenous food and beverage processing, the revitalization of traditional hand woven ikat textiles and the development of small community-based ecotourism including forest and river trek activities (Kirana, 2019).

As observed in research regarding the indigenous peoples and the rainforests of Borneo, the island's rainforests are one of the world's richest sources of biodiversity, and its indigenous peoples have been living in these rainforests for over 45,000 years (Sellato, 2012). Given their close relationship with the forest, the Iban have acknowledged and gathered knowledge regarding many plants that are suitable for creative works such as fibers and natural dyes (Sellato, 2012). These natural materials that have been developed for the Sui Utik art works include resam, bemban, rattan, wild pumpkin and wild mango. All the materials came from the forest surrounding Utik river (Kirana, 2019).

The following discussion of the creative works of the Sui Utik community can be classified under the natural materials from which they are made and which have been sustainably sourced from the local surrounds, or, in the case of ecotourism treks, are based in the local ecosystem.

\section{Resam product}

Resam is the inner part of a fern that grows on the forest floor. It is used as the black material for weaving, while rattan is used as a complementary yellow fibre (Figure 5). The two different fibres are woven together to make a bracelet. When Sekar Kawung visited Sui Utik in 2015, this kind of bracelet was no longer made. The Sui Utik said: "it was kuno (old fashioned)" (Kirana, 2019). However, Sekar Kawung asked them to resume making the bracelet and suggested some design development and refinement for smoother quality. It is now a favorite product and the bestselling item among all the creative materials the community makes. According to tradition, the ancestors believed that wearing this bracelet would discard all the bala (bad luck) in the forest, such as rattlesnakes. Now, as Kirana, notes, it is a bracelet that travelers like (Kirana, 2019). 

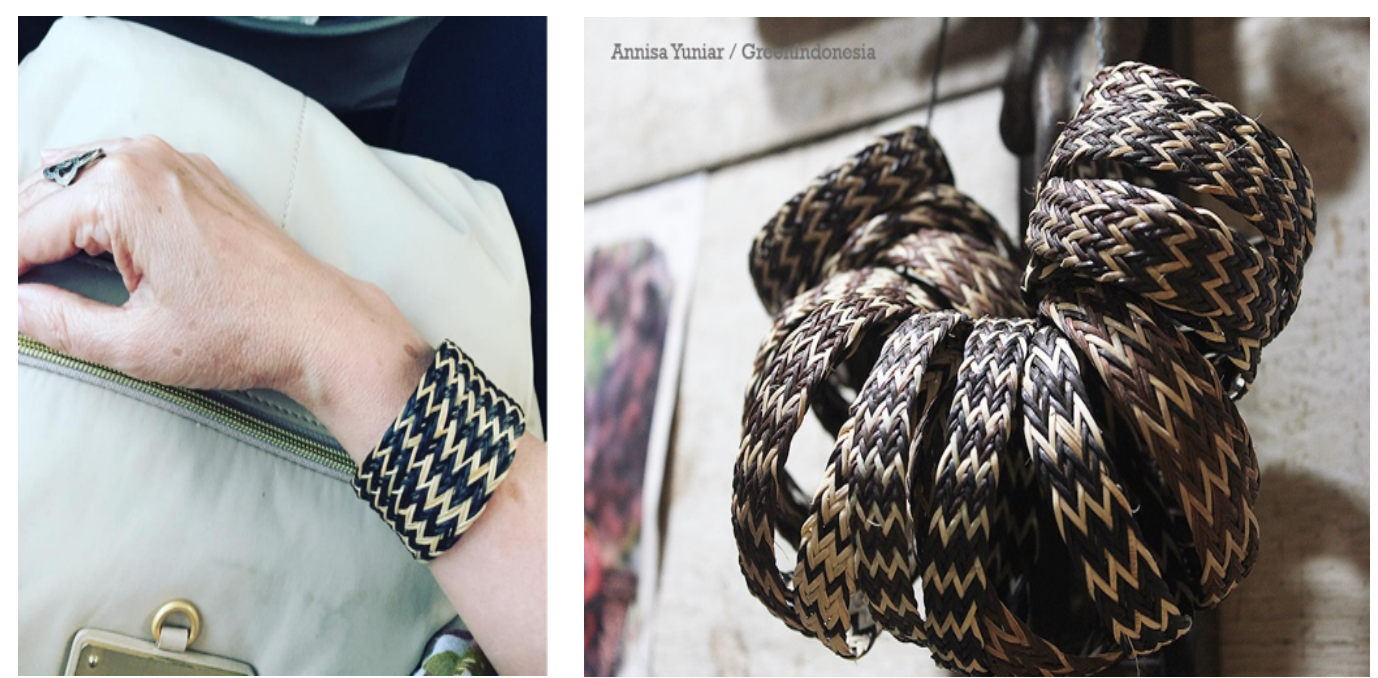

Figure 5: Natural bracelets (Yuniar \& Kirana, Natural Bracelet, 2015)

\section{Bemban product}

Bemban (Donax cannaeformis) is a type of water plant that, for the Iban, is very useful as a material for making natural mats (Figure 6). Inherited bemban mats are a source of pride for weavers, who are mainly women. Woven mats are used for certain ceremonies and are proffered for seating of guests of honour in Iban houses. The mats incorporate traditional patterns created by gifted weavers who have special abilities to create and weave the pattern. On their wrists the weavers bare the Tegulun tattoo, an ancient tattoo design that indicates their ability and status. The motifs on the mats are inspired by nature, such as plants and animals, and by the spirits of ancestors. According to local belief, originally the motif design was derived from the power of imagination and dreams about antu (spirits) (Yayasan Riak Bumi, 2019).

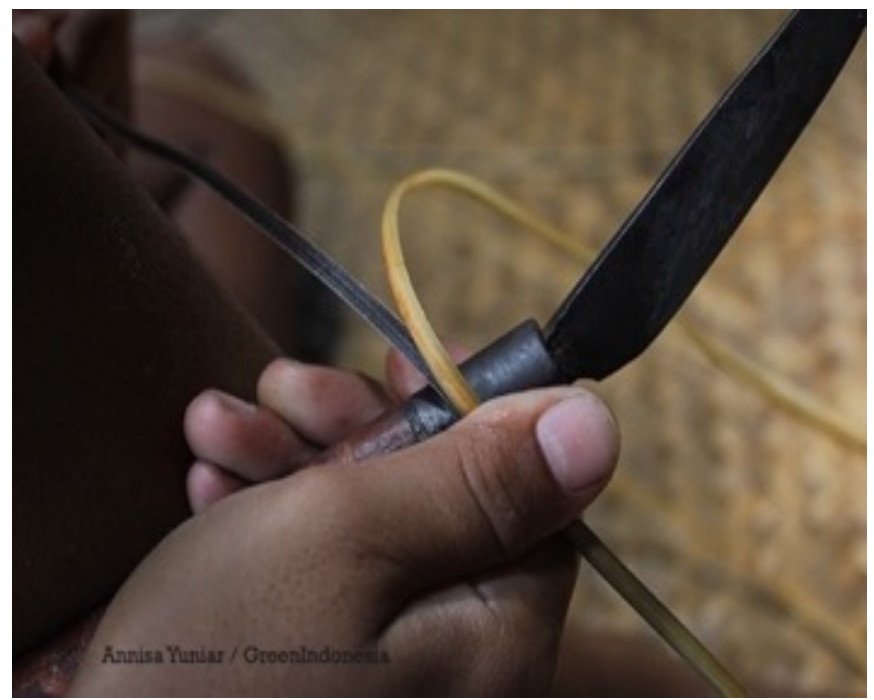

Figure 6: Bemban, natural material from Utik forest (Yuniar \& Kirana, Bemban, 2015) 
In one conversation with Chandra Kirana, the founder of Sekar Kawung commented:

One of my favorite woven mats is made from a very small bamboo plant locally known as bemban (Figure 7). The gifted craftsmen weave the natural mat with the motif that enters subtly into their heart. Almost all traditional motifs of the natural mat are inspired by the leaves of the fern tendrils and indigenous animals. Once, they said that they have an ancient motif with a shape like a line of UFOs that later on they called motif pesawat (airplane). Unfortunately, I could not find the picture of that motif. (Kirana, 2019).
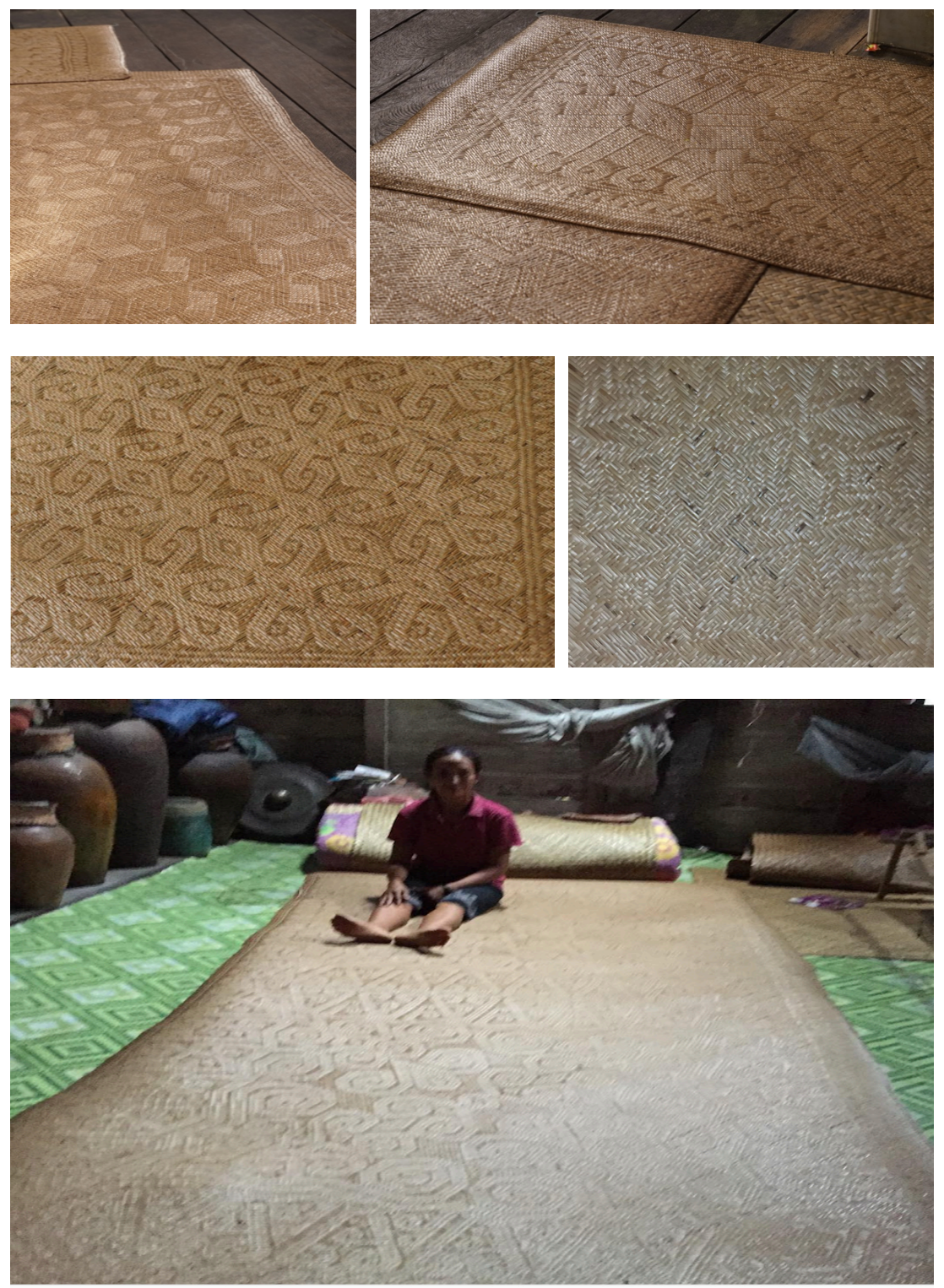

Figure 7: Natural mat inspired by ancient Iban patterns (Kirana, Natural Mat, 2015) 
The photograph at the bottom of Figure 7 shows the woven mat with the weaver mamak Bayu (Mrs Bayu). In another conversation with Chandra Kirana, she elaborated that:

Mamak Bayu wove this beautiful mat (Figure 7) but did not intent to sell it because she fell in love with the piece, and I did too. In her village, once a year, they have the gelai tikai (unroll the mat) ceremony. In this ceremony everybody brings their best hand woven mat to the longhouse hall and rolls it out for all to sit on. It is part of an annual ritual to thank mother nature for her bounty (Kirana, 2019).

The mat designs are named after natural phenomena. There are three categories for names: plants and trees, humans and animals, and meteorological and geographical terms (Sellato, 2012, p. 334).

\section{Rattan product}

Kalimantan "is home to more than 144 different rattan species and 95 of them are only found in Borneo" (Anderson, 2002). Rattan is the collective name for approximately 600 species of palm in the Calameae family, of which the majority are forest species. The plants have thorny stems and leaves which are used to cling to the supporting structure of other plant species (Meijaard et al., 2014). In their raw, natural state, rattan plants do not at first appear favourable for creative products due their being covered by copious and vicious-looking spines and thorns (Sellato, 2012). Nevertheless, harvesting rattan can be a sustainable way for local people to make a living. Furthermore, because rattan requires large trees to grow up, the plant encourages communities to conserve and restore their forest (WWF, 2017).

Rattan basket weaving in Sui Utik had not developed as extensively as is the case with other communities in various parts of Kalimantan. Sekar Kawung therefore concentrated on helping to develop the design based on the familiar Sui Utik weaving technique already established, but asked the weavers to reverse the smooth material so it became the outer design, thus developing the design to fulfil contemporary functional qualities in keeping with market demands (Figure 8) (Kirana, 2019). 

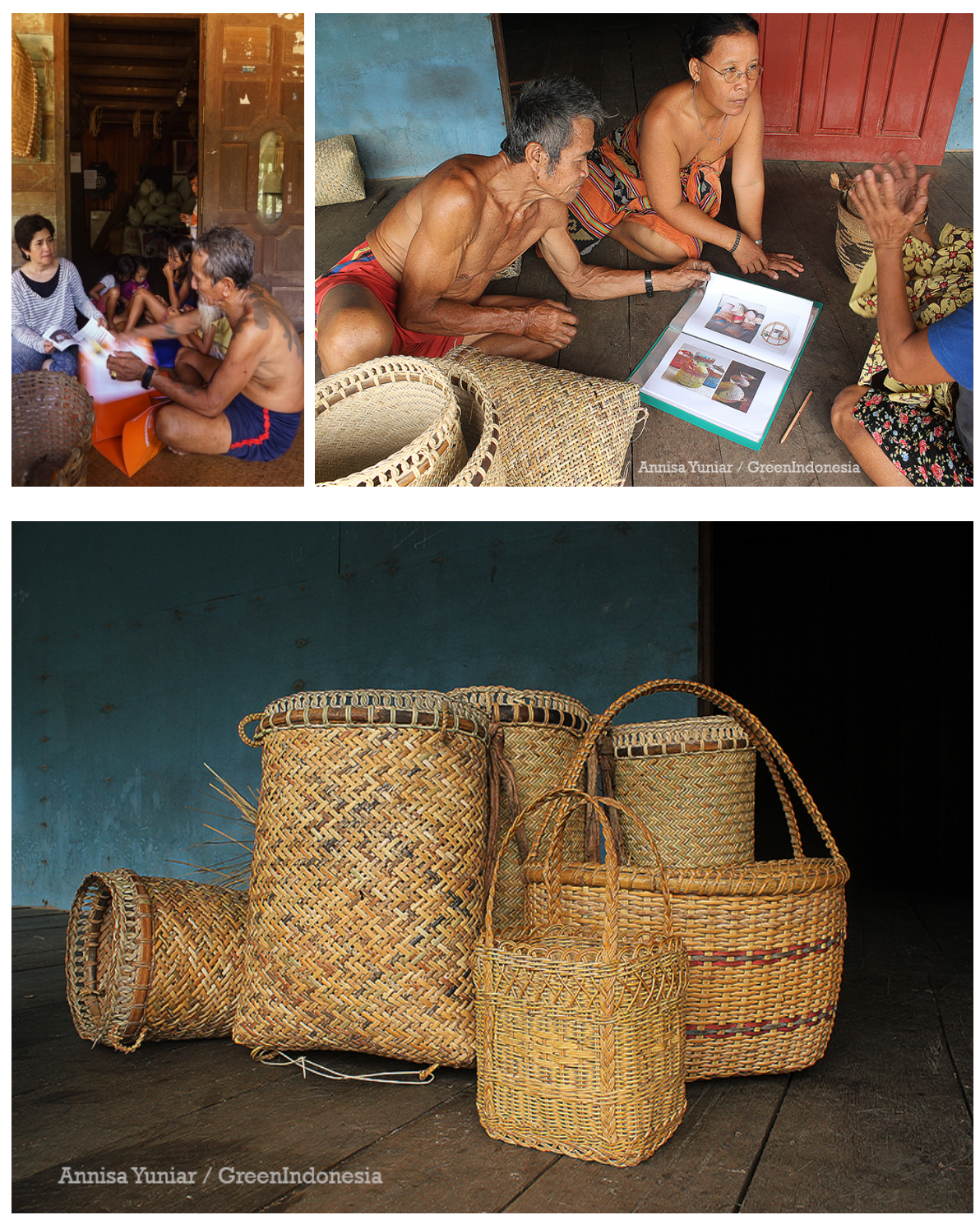

Figure 8: Rattan basket weaving of Sui Utik (Yuniar \& Kirana, Rattan Weaving, 2015)

The anthropologist Bernard Sellato (2012) observes that in the long history of Iban weaving, these indigenous people have been using rattan to create numerous products for their quotidian life needs. His extensive research in Kalimantan revealed at least six types of common Iban twills: anyam apit, anyam tunggal or anyam buah, anyam dua jarang (open 2/2 twill), anyam apitbekalih (reverse side of anyam apit), anyam tiga, anyam mata ulat (figure 9). He noted that the differences between these six twills are the pattern of the interlacement and the use of pattern in the design. The patterns of anyam apit (figure 9 no. 1) and anyam tunggal (figure 9 no. 2) are the two most common interlacements which are woven into lban baskets for daily use, while the anyam mata ulat (figure 9 no. 6) is a motif of ritual baskets based in Iban traditional belief (Sellato, 2012, p.105). 

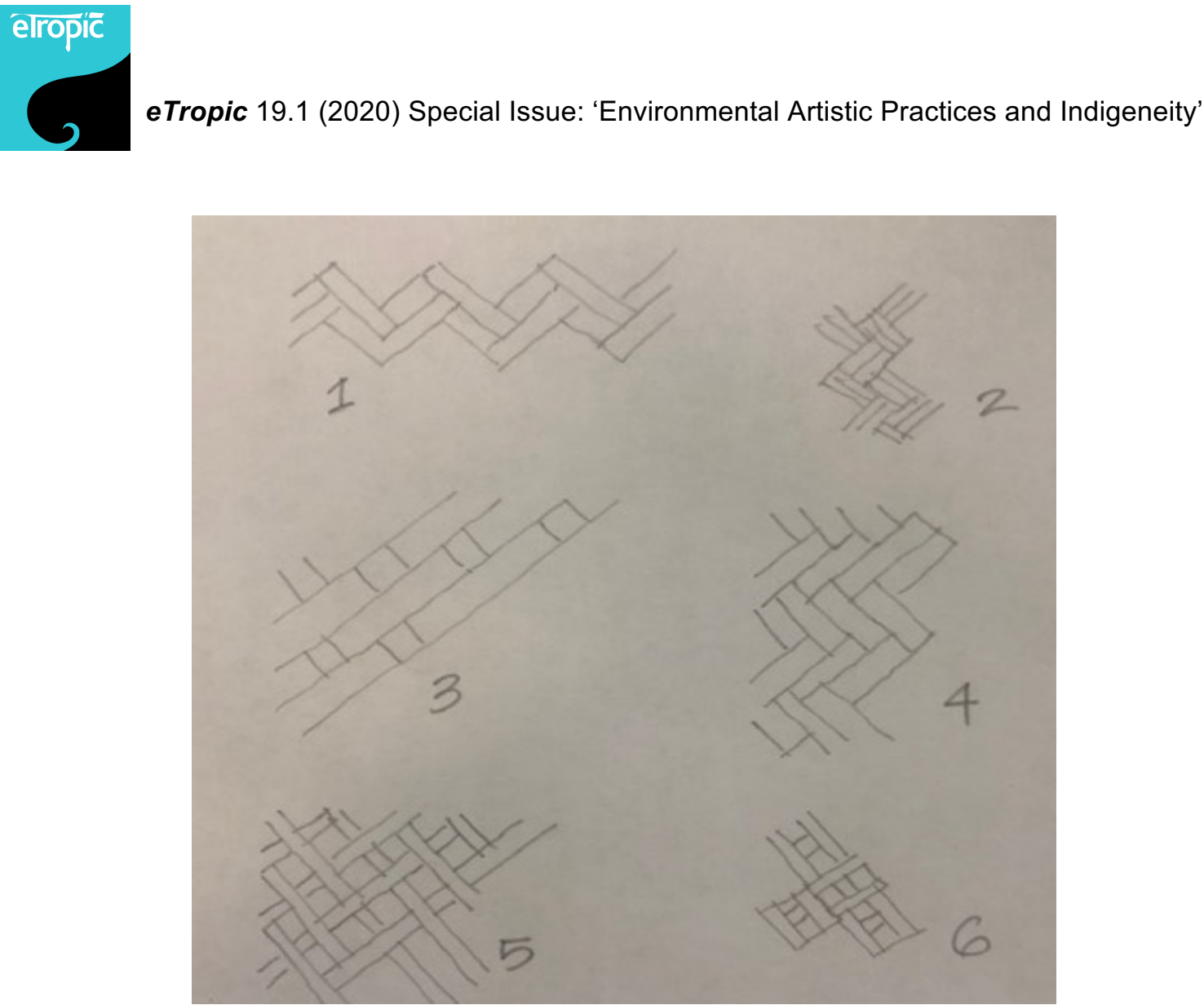

Figure 9: 1. anyam apit, 2. anyam apitbekalih (reverse side of anyam apit), 3. anyam tunggal or anyam buah, 4. anyam tiga, 5. anyam dua jarang (open $2 / 2$ twill), 6 . anyam mata ulat (Sellato, 2012, p. 105)

In the Tembawang system, the land is planted with various types of plants to enable the forest to produce a variety of natural materials, but in a limited number and according to different harvest seasons. Due to this seasonal system, the arrangement and use of different materials in each design, and the possibility of replacing each material for an alternative material is very important. All products that use resam, bemban and rattan are designed with consideration of natural harvesting periods according to seasons, and can be a substituted for one another.

The economic value of the creative products using a limited number of natural materials such as resam, bemban and rattan, under principles of good design, is higher in comparison to selling raw materials directly from the forest. This ecologicaleconomic condition acts to encourage craftsmen from Sui Utik to continue to implement forest management in line with the Tembawang system.

\section{Wild Pumpkin product}

Wild labu (pumpkin) is a bottle gourd of the species Lagenaria siceraria (Molina) Standley (family Cucurbitaceae). The plant belongs to the hard-textured pumpkin varieties. The gourd shape ranges from rounded to oval with a length of $10-100 \mathrm{~cm}$. This plant easily adapts to various weather conditions, including rainy or dry seasons. 
Archaeological research indicates that the wild pumpkin is one of the oldest cultivated plants, planted not for food, but rather to be used as household utensils (Greeners, 2019).

Sekar Kawung worked with artisans of Sui Utik to develop the wild labu (pumpkin) into a creative product by enhancing the raw material with tattoo designs, which are drawn onto the gourd. Thus the Iban body tattoo technique is repurposed in the decoration of gourds for the contemporary market. The principle gourd design is inspired by an ancient Iban motif (Figure 10).
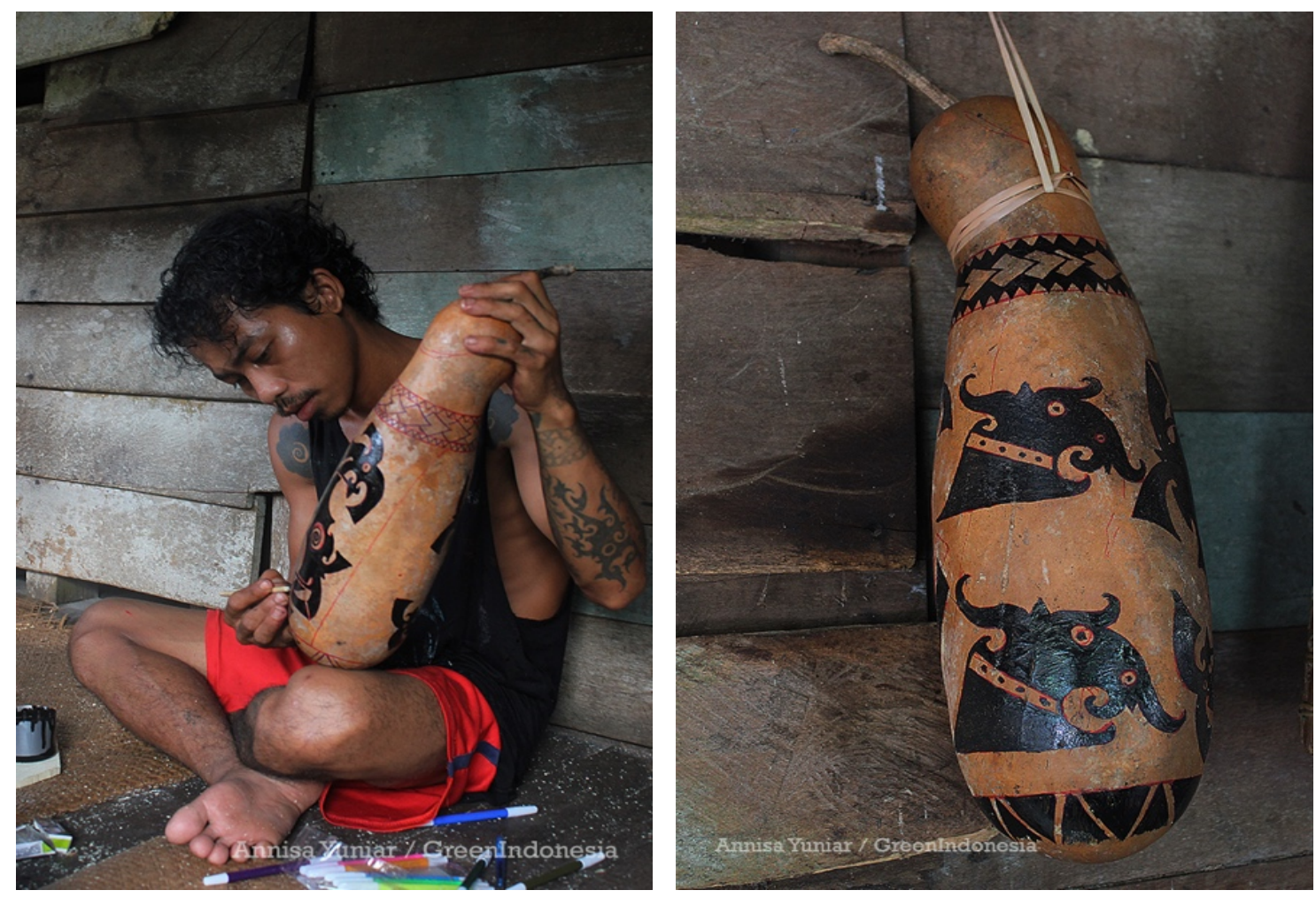

Figure 10: Wild labu (pumpkin) with the pattern inspired by an ancient Iban motif

(Yuniar \& Kirana, Wild Labu, 2015)

Wild pumpkin is one of the agroforestry products in Sui Utik in keeping with the Tembawang system. The creative development of this wild pumpkin as a souvenir increases the value of the plant. Increasing the value of forest products, in turn, enhances the sustained implementation of the Tembawang agroforestry practice.

\section{Mawang product}

Mawang (species Mangipera) is found in West Kalimantan where it grows wild in the forests, but may also be planted or dispersed by local people. This fruit tree with characteristic wide leaves grows over 30 metres tall and bares large round fruit, with 
a brown rind and fibrous inside which has a sour flavour (Kalbar Litbang Pertanian Indonesia, 2019).

Sekar Kawung has collaborated with Sage Livingfood and the Sui Utik community to develop various products from this forest fruit which, due to its mango orange fibrous pulp, is referred to as wild mango. Food and beverage products include: cordial, syrup, jam and vinegar. The fruit, which is only found in some areas of Kalimantan and forms part of the traditional diverse agroforestry systems belonging to the Dayak Iban tribes, is of particular interest as an indigenous food (Figure 11) (Kirana, 2019).
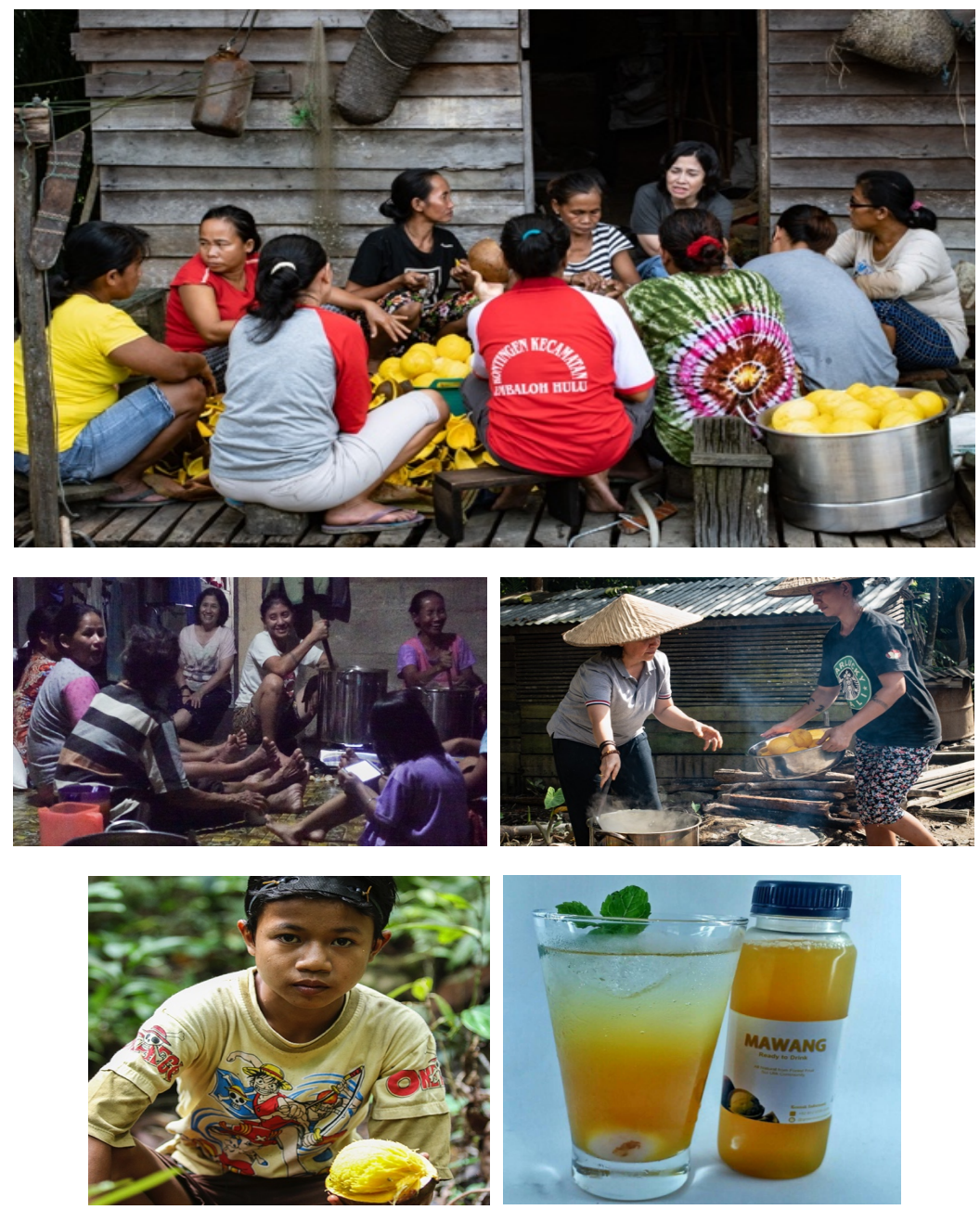

Figure 11: Mawang, the rainforest wild mango of Utik river. The fruit is not usually eaten, but can be processed into syrup and jam (Kirana, Wild Mango, 2015)

The mawang tree grows widely in the Sui Utik agroforests. The fruit is copiously abundant in certain seasons, however, as it tastes very sour, the fruit is not good to eat and thus is wasted and not considered of value. Processing this wild forest fruit as 
a product with more economic value simultaneously creates a value chain that helps to maintain the agroforestry system.

\section{Textile Weaving product}

As has been noted by many researchers of textile traditions as part of the intangible heritage of Kalimantan that: "The decline in textile production among the Dayaks, as in the case of most traditional arts, was a consequence of general forces of culture change, modernisation and development" (Kreps, 2013, p. 179). This likewise was the case in Sui Utik, especially in the case of ikat textiles made from natural cotton and dyes. When Sekar Kawung foundation first visited the area, the Dayak Iban people in Sui Utik no longer practiced this woven textile craft. In order to try to reestablish the tradition, Sekar Kawung first brought eco yarn from Java for the women of Sui Utik as a starter material for them to begin weaving. Sui Utik textiles have a unique simple and strong aesthetic. The designs are inspired by the shape of fern fronds found on the rainforest floor around the Utik river. Figure 12 is another mamak Bayu (Mrs Bayu) design. Chandra Kirana comments: "She knows all the secrets of how to thrive with nature's bounty. Her designs are so nourishing for the soul” (Kirana, 2019).
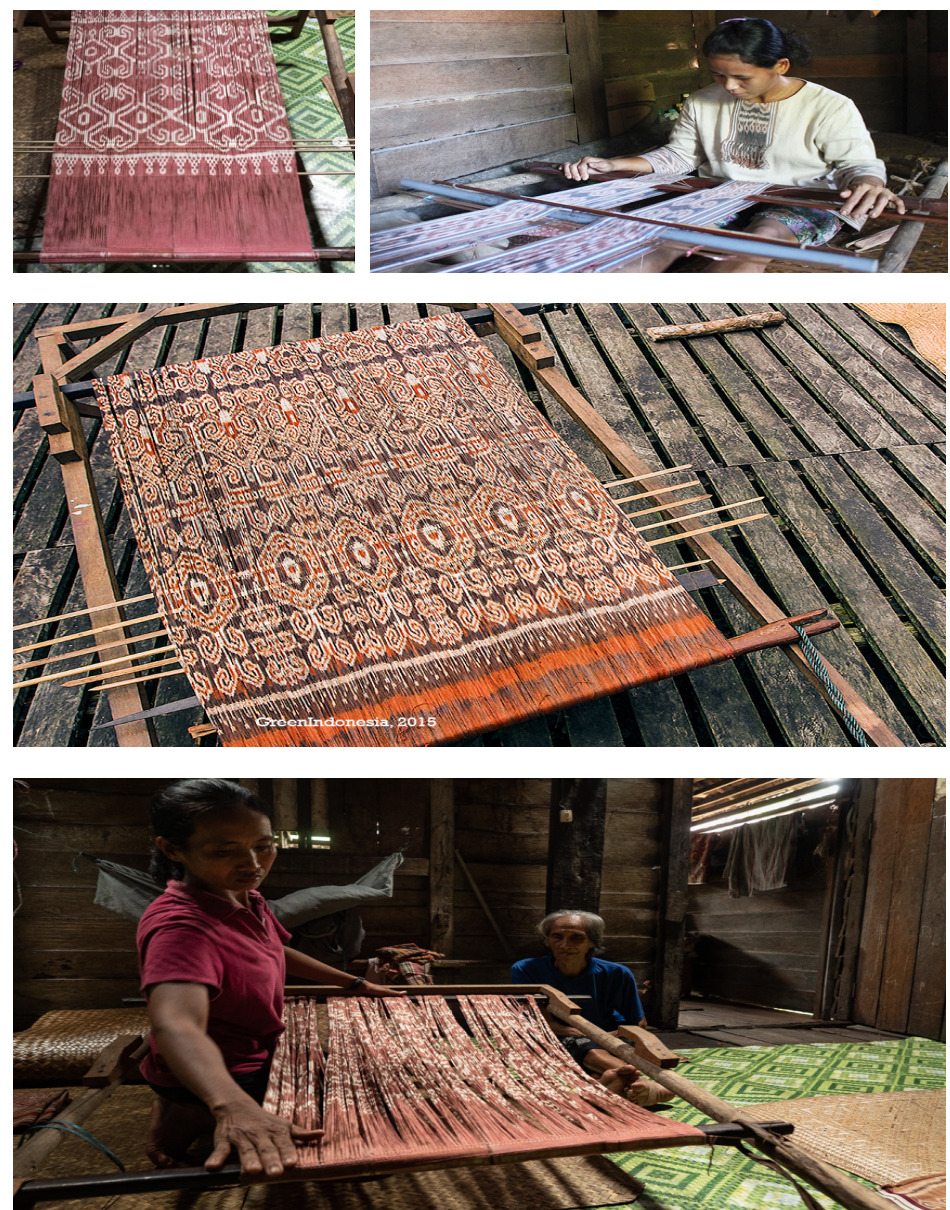

Figure 12: Woven textiles of Sui Utik (Yuniar \& Kirana, Woven Textile, 2015) 
The tropical rainforests of Utik river, in combination with the Tembawang system, produce a variety of plants that can be used as natural dyes. Thus the revitalization of the tradition of textile weaving for the community in Sui Utik is to simultaneously retain awareness of the usefulness of various forest plants. Weaving activities help preserve the source materials for natural dyes.

\section{Ecotourism Jungle Treks}

Sekar Kawung together with the Sui Utik community has designed jungle treks as part of an ecotourism program in the rainforest region of Utik river. The ecotourism initiative first created various embryotic tour packages which were then refined. In 2015 the Sui Utik experience was chosen as one of the 'Beautiful Indonesia' tourism programs with the assistance of the Government of Indonesia, the Indonesian Ministry of Tourism and the Embassy of the Republic of Indonesia in Oslo, Norway (KBRI Oslo). Sekar Kawung escorted travel and lifestyle journalists from Norway on a familiarisation trip to the Utik River (figure 13) (Kirana, 2019).
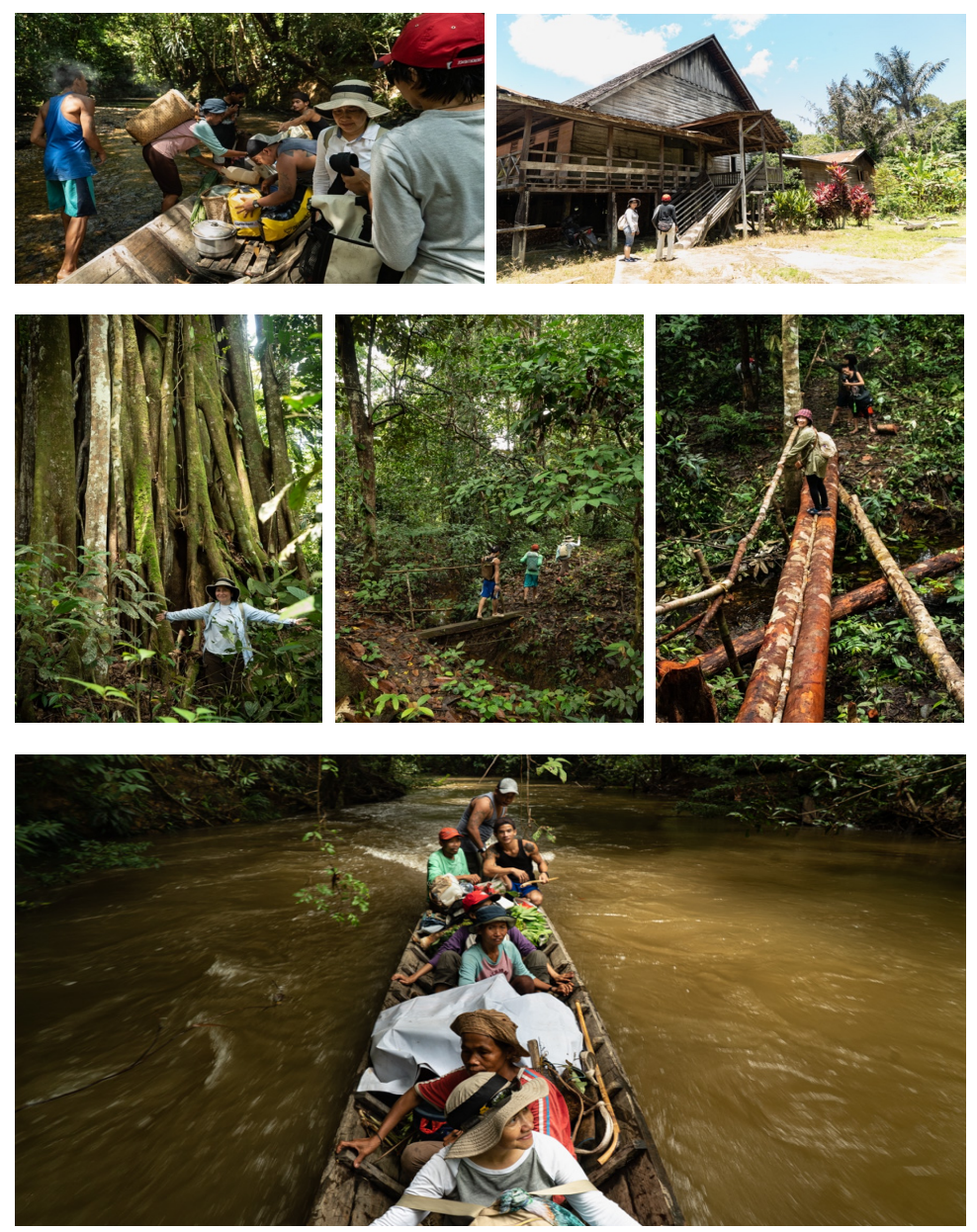

Figure 13: Jungle trek of Utik river and rainforest (Kirana, Jungle Trek, 2015) 

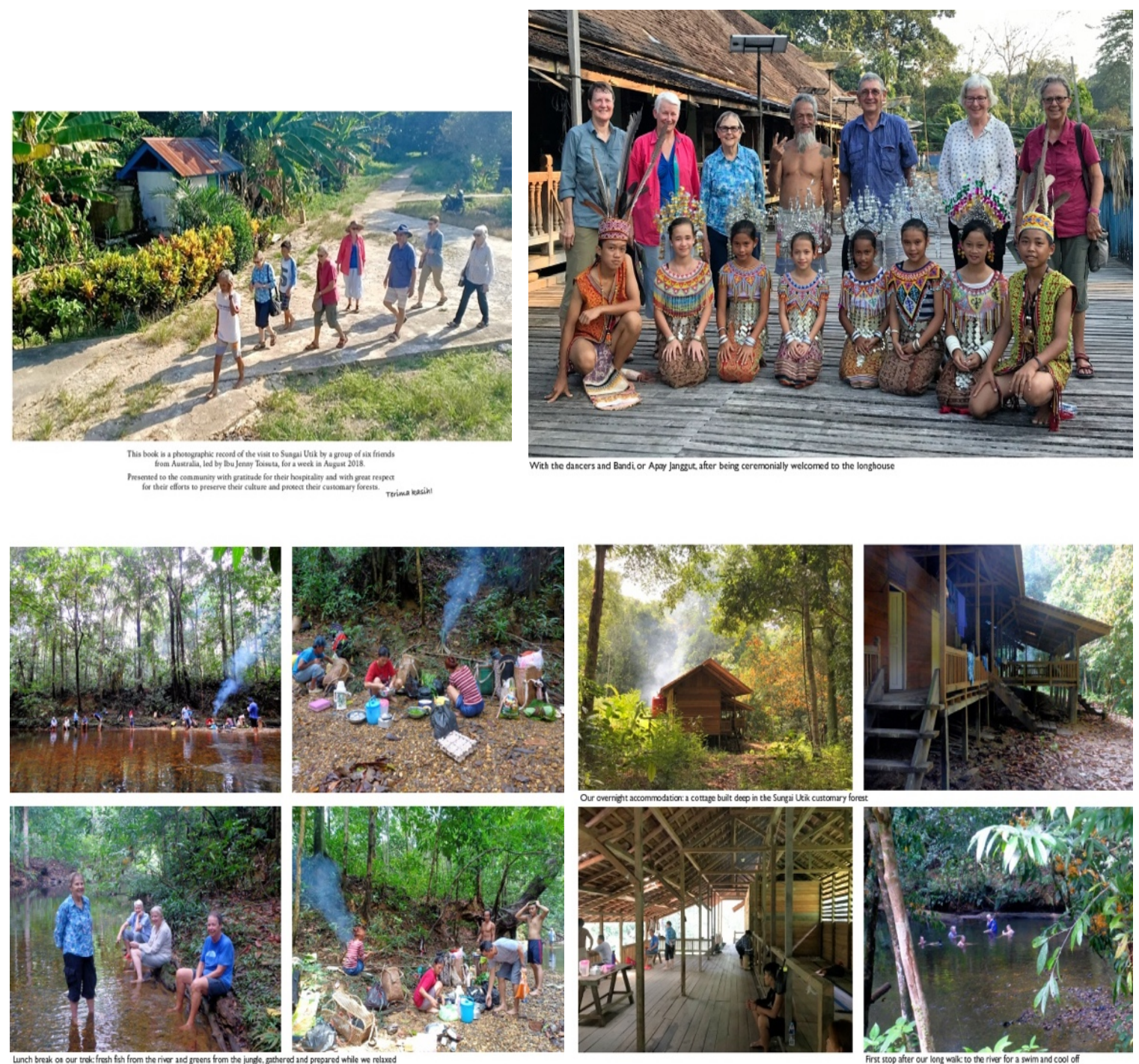

Figure 14: Photographic documentation of visitors on the jungle trek route in Utik river and rainforest (Toisuta \& Kirana, Jungle Trip, 2018)

Figure 14 is part of the photographic record of a visit to Utik river by a group of six Australians led by Jenny Toisuta in August 2018. The images show aspects of the ecotourism and jungle trek route planned by the Sui Utik community and Sekar Kawung. Other small ecotourism groups have likewise arranged trips to Sui Utik in order to experience the nature, culture and heritage that are sustained by the practices of Tembawang (see, for instance, Brookes, 2019).

The land use system of Tembawang by planting and maintaining various types of plants, from long-lived large trees such as tengkawang (Borneo tallow nut), jelutung and nyatuh (banyan) with diametres over one metre, to understorey plants and grasses, has the potential to balance the macro and micro climate setting around it 
(Soeharto, 2010, p.10). This ecology and its biodiversity makes Sui Utik both climatically comfortable and also beautiful to visit.

Jungle design tracks that follow the conditions and contours of forests and natural resources in Sui Utik make the program of jungle trekking unique to the local landscape of forests, rivers, flora and fauna, creating interesting and challenging routes for tourists. The trekking program brings increased economic value to the inhabitants of Sui Utik in comparison to the economic value of logging and timber sales. Jungle treks are held throughout the year while gains from timber sales are temporary, lasting only as long as each logged tree and only as long as the forest trees exist. Thus, the jungle trek program holds an inherent positive influence for the preservation of forests and nature in Sui Utik.

\section{Conclusion and Suggestion}

The creative works that have been produced in Sui Utik are pertinent examples of combining cultural and economic value within the understanding of local wisdom. The products which have been designed using indigenous materials from the forest - such as resam, bemban, rattan, wild pumpkin, mawang and natural dyes - have been managed using the Tembawang system. The products use materials that are harvested according to the cycle of seasons without being overly reliant on one kind of material and season.

Embedding the local wisdom of Tembawang in the design of creative products helps the Sui Utik community continue to take pride in their natural and cultural heritage at a time in which new manmade materials have become widely accessible and have been "viewed as more durable and easier to prepare or plait [weave] as compared with traditional materials and were thus considered a more attractive choice" (Sellato, 2012, p. 468). As further noted by Sellato: "Older forms and types [of materials and crafts] may or may not be retained along with new ones." And he concludes, "as older functions fall into disuse, so do the craft forms associated with them" (Sellato, 2012, p. 468). Thus, the revitalization of traditional crafts is necessary to counteract the attrition of indigenous creative practices and their local wisdom.

The Sui Utik community in collaboration with Sekar Kawung, has developed a creative works practice based in a sustainable value chain which retains and restores indigenous rainforest flora by implementing the concept of Tembawang. To complete the value chain, the creative works practice should move towards the international market. Such marketing is not just economics; it further acts to maintain the production of these creative products. As argued by Joop Ave et al.: "craft making will continue to 
have a place in global market where everything is potentially available at an affordable price because of the fact that craftmanship and the associated skills have context and meaning and are recognized as a component of heritage" (Ave et al. 2008). The Sui Utik creative works which consistently use natural material within a core value of indigenous wisdom are of value in sectors of the international market place. In turn, international recognition will motivate the community to continue to preserve the environment and to close the loop of the sustainable value chain.

Internationalisation can be implemented by marketing the Sui Utik together with other Indonesian indigenous creative producers in order to open wider opportunities. The marketing aspect could be done by working together with designer communities under Sekar Kawung as the concept designer of the whole value chain. The use of contemporary marketing tools such as a website and apps can be developed with the assistance of web/app designers. The Sui Utik should be consulted and involved in the development of the branding and marketing as pertains to their creative products, their wisdom, and their expertise. Training in technical aspects of online marketing should be introduced to members of the community so they can view the website/app with the aim of inspiring further technical interest within the community.

In regards to the ecotourism program, the practice should note that the "first attitude was to adopt the localized approach of the ethnologist" (Picard, 2001). In other words, all the creative works, including the design of jungle treks are based in the local wisdom of Tembawang, and this system should be seen in every aspect of the program. This does not prevent the community from improving the program by using technology to promote and market it. The community should increase the market for the ecotourism jungle trek program by opening an artisan gallery and store in Sui Utik while also promoting the creative works through a website gallery in order to reach global markets.

However, the development of tourism in Sui Utik, as with all tourist spots - whether small communities or cities - also has to take into consideration that even as tourism generates income and employment and even though liveliness and livability can be boosted, the (social) sustainability of tourism has to take into consideration the tolerance level of the local community (Postma \& Schmuecker, 2017). In the case of Sui Utik, it also has to assess the tolerance level of the local ecosystem in keeping with the wisdom of Tembawang.

Importantly - for the community of Sui Utik and the social enterprise and design communities involved in helping them develop and market their creative products - it must be remembered that 'at the root', all these creative works have been developed in respect to Tembawang, the indigenous agroforestry concept of the Dayak Iban 
people. Thus, all the details of the value chain must regard this core concept as its root. Likewise, this 'root' must be carried forward into the design and development of strategies for an international market.

The internationalisation of Sui Utik creative works is not antithetical to their 'root' in Tembawang wisdom. Tembawang has been vigorously used as an active ideology in the conservation of rainforest areas in Kalimantan, Borneo, which have faced intense encroachment and deforestation by multinational companies. The Dayak Iban of Sui Utik are acutely aware of the multiple environmental problems of large scale land clearing, including the massive burn offs which create high levels of air pollution across regional borders. The creative works of Sui Utik, sourced from raw materials of the rainforest and embedded in local wisdom are themselves the material embodiment of Tembawang. Thus, in reaching an international market, each product carries the wisdom of cultural and environmental heritage into the wider world. 


\section{References}

Aaberge, B., Barnard, T., Greer, S. \& Henry, R. (2014). Designs on the Future: Aboriginal Painted Shields and Baskets of Tropical North Queensland, Australia. eTropic 13 (2), 56-74. DOI https://doi.org/10.25120/etropic.13.2.2014.3314

Ananda, M. (2019). Children. Palangkaraya: Ranu Welum Foundation and Youth_actkalimantan.

Anderson, J. (2002). Priority Areas for Rattan Conservation on Borneo. University of Copenhagen.

Antaranews. (2019, October 5). Antaranews. https://en.antaranews.com/news/133398/indonesian-forest-fire-chokes-millions-ofpeople-animals

Ave, J., Hitchcock, M., Jay, S.E., \& Gustami, S.P. (2008). Indonesian Arts and Crafts. Jakarta: BAB Publishing Indonesia.

Baral, H., Jaung , W., Bhatta , L. D., Phuntsho, S., Sharma, S., Paudyal, K., Zarandian, A., Sears, R.R., Sharma, R., Dorji, T., \& Artati, Y. (2017). Approaches and tools for assessing mountain forest ecosystem services. Working Paper, 235. Center for International Forestry Research (CIFOR). DOI: https://doi.org/10.17528/cifor/006755

Brookes, S. (2018, 3 April). Life in a Longhouse Sungai Utik Village. NOW! http://nowjakarta.co.id/art-and-culture/hidden-heritage/life-in-a-longhouse-sungai-utikvillage

Damkar, C. K. (2019). Forest fires in Central Kalimantan. Palangkaraya: Ranu Welum Foundation.

El-Haggar, S.M. (2007). Sustainable Industrial Design and Waste Management: Cradle-tocradle for Sustainable Development. Academic Press. https://doi.org/10.1016/B9780-12-373623-9.X5000-X

Foresta, H. D., \& Michon, G. (1997). The agroforesta alternative to Imperata grasslands : When smallhorlder agriculture and forestry reach sustainability. Agroforestry Systems, 36, 105-120.

Greeners. (2019, June 25). Greeners. www.greeners.co

Idhom, A. M. (17 September 2019). Causes and Effects of Forest Fires in Kalimantan to Sumatra. Tirto. https://tirto.id/penyebab-dan-akibat-kebakaran-hutan-di-kalimantanhingga-sumatera-eic3

Kalbar Litbang Pertanian Indonesia. (2019, June 25). Kalbar Litbag Pertanian. http://kalbar.litbang.pertanian.go.id

Kirana, C. (2015a). Jungle Trek. Sui Utik: Sekar Kawung.

Kirana, C. (2015b). Natural Mat. Sui Utik: Sekar Kawung.

Kirana, C. (2015c). Wild Mango. Sui Utik: Sekar Kawung.

Kirana, C. (2019). Personal Communication, July 12 \& 18. (O. S. Caroline, Interviewer).

Kirana, C. (2019). Sekar Kawung Value Chain. Bogor: Sekar Kawung.

Kreps, C. (2013). Intangible Threads: Curating the Living Heritage of Dayak Ikat Weaving. In Stefano, M.L., Davis, P. \& Corsane, G. (Eds). On the Ground: Safeguarding the Intangible (pp. 177 -194). Boydell \& Brewer.

Laman, S. (2019). Firefighters. Palangkaraya: Ranu Welum Foundation and Youth_actkalimantan.

Lamb, K. (2019, October 5). The Guardian. https://www.theguardian.com/world/2019/sep/12/indonesia-forest-fires-spark-blamegame-as-smoke-closes-hundreds-of-malaysia-schools

Locatelli, B. (2016). Ecosystem Services and Climate Change. In M.Potschin, R. HainesYoung, R. Fish, \& R.K.Turner, Routledge Handbook of Ecosystem Services (pp. 481490). London \& New York: Routledge. 
Meijaard, E., Achdiawan, R., Wan, M. \& Taber, A. (2014). Rattan, The decline of a onceimportant non-timber forest product in Indonesia. Bogor: Center for International Forestry Research.

Millennium Ecosystems Assessment (2005). Ecosystems and Human Well-being. Island Press. https://www.millenniumassessment.org/documents/document.356.aspx.pdf

Muryati, M. \& Rokhiman, R. (2016). Bambi Ari' Sebagai Wujud Kearifan Lokal Masyarakat Dayak Dalam Penanganan Bencana Kabut Asap Di Kabupaten Kapuas Hulu, Kalimantan Barat. Sosiologi reflektif, 11(1).

PACWA. (2019, October 8). Deforestation - effects on Air Pollution. https://www.pacwa.org/deforestation-effects-on-air-pollution/

Picard, M. (2001). Bali: twenty years of research. Anthropologie et Sociétés, 25 (2), 109-127.

Postma, A., \& Schmuecker, D. (2017, September 11). Understanding and overcoming negative impacts of tourism in city destinations: conceptual model and strategic framework. Tourism Futures, 3(2), 144-156.

Rainforest Action Network. (2019, October 10). https://www.ran.org/indonesian-rainforests/

Sellato, B. (Ed.) (2012). Plaited Arts from the Borneo Rainforest. Jakarta: Lontar Foundation; Singapore: NUS Press; Copenhagen: Nordic Institute for Asian Studies Press, NIAS Studies in Asian Topics 48; Honolulu: University of Hawai'i Press.

Soeharto, B. (2010). Tembawang: bukan sekedar sistem agroforestri. Kiprah Agroforestri World Argroforestry Center Indonesia, 3(3), 10-11.

Susanto, E., Lestari, N., Hapsari, M., \& Krisdyatmiko. (2018). Driving Factors of Deforestation in Indonesia: A Case of Central Kalimantan. Jurnal Studi Pemerintahan, 9(4), 511- 533. https://journal.umy.ac.id/index.php/jsp/article/view/5170

Toisuta, J., \& Kirana, C. (2018a). Iban House, An Amazing Week in Sungai Utik, Iban Dayak Community, West Kalimantan. Sui Utik: Sekar Kawung.

Toisuta, J., \& Kirana, C. (2018b). Jungle Trip. Sui Utik: Sekar Kawung.

WWF (2019). Borneo Deforestation. https://wwf.panda.org/our work/forests/deforestation fronts2/deforestation in borne o and sumatral

WWF (2017, 26 June). Rattan Keeps Forests Standing in Borneo. WWF Newsroom. https://gftn.panda.org/newsroom/index.cfm?uNewsID=303570

Yayasan Riak Bumi. (2019). www.riakbumi.or.id

Youth_Actkalimantan. (2019a). Babies. Palangkaraya: Ranu Welum Foundation and Youth actkalimantan.

Youth_Actkalimantan. (2019b). Firefighter in Central Kalimantan. Palangkaraya: Ranu Welum Foundation and Youth_actkalimantan.

Youth_Actkalimantan. (2019c). Old People. Palangkaraya: Ranu Welum Foundation and Youth_actkalimantan.

Yuniar, \& Kirana. (2015a). Bemban. Sui Utik: Green Indonesia.

Yuniar, \& Kirana. (2015b). Natural Bracelet. Sui Utik: Green Indonesia.

Yuniar, \& Kirana. (2015c). Rattan Weaving. Sui Utik: Green Indonesia.

Yuniar, \& Kirana. (2015d). Utik River and Rainforest. Sui Utik: Green Indonesia.

Yuniar, \& Kirana. (2015e). Wild Labu. Sui Utik: Green Indonesia.

Yuniar, \& Kirana. (2015f). Woven Textile. Sui Utik: Green Indonesia. 


\section{Acknowledgements}

I would like to thank Mrs Chandra Kirana from Sekar Kawung foundation for our conversations and her encouragement; and Darren Whiteside, Aji Yahuti and Sumarni (Youth_actkalimantan/Ranu Welum Foundation) for their support for this paper.

Octaviana Sylvia Caroline Rombe is an architect who graduated from the Parahyangan University, Indonesia and the Catholic University of America, Washington D.C. She is currently pursuing her PhD in Sustainable Urban and Regional Planning at the Faculty of Built Environment, University of Malaya, on research in the area of Indonesian local wisdom and sustainable value chains supporting community development in areas of Indonesia. Octaviana is a lecturer in the School of Design at Bina Nusantara University, Indonesia. 